\title{
Adherence to hand hygiene at five moments and specific protection in a tertiary care hospital during the COVID-19 pandemic
}

Javier A. Maciel-Urzúa, ${ }^{1}$ Gabriela Zamudio-Martínez,, Goretti Rangel-León, ${ }^{3}$

Mauricio E. Bustamante-Morales, ${ }^{1}$ Rodrigo A. Del Valle-Díaz de León ${ }^{4 *}$ and José V. Pérez-Navarro ${ }^{1}$

${ }^{1}$ General Surgery Department, Centro Médico Nacional de Occidente, Instituto Mexicano del Seguro Social, Jalisco; ${ }^{2}$ General Surgery Department, Regional General Hospital 46, Instituto Mexicano del Seguro Social, Jalisco; ${ }^{3}$ Internal Medicine Department, Hospital Regional de León, Instituto de Seguridad y Servicios Sociales de los Trabajadores del Estado, Guanajuato; ${ }^{4}$ Ophthalmology Division, Specialty Tower, Hospital General "Dr. Manuel Gea González", Mexico City. Mexico

\begin{abstract}
Introduction: During the COVID-19 pandemic, adherence to hygiene measures is an objective aimed at reducing morbidity and mortality. Objective: To evaluate adherence to hand hygiene and protection measures during the COVID-19 pandemic in a tertiary care hospital. Methods: Cross-sectional study on health personnel handwashing at the five moments recommended by the World Health Organization, as well as on the use of specific personal protective equipment. Results: One hundred and seventeen hand hygiene opportunities were observed in health personnel. Hand washing was observed in 40 (34\%) and omission in 76 (65\%). Adherence to the use of face shield was observed in five (4\%), and lack of adherence in $112(96 \%)$. Adherence to the use of face mask was observed in 65 nursing professionals (87\%), with appropriate use of the mask in 56 of them (60\%) and use of face shield in one (1\%). Conclusion: Health personnel showed low proportions of adherence to hand hygiene and use of equipment for specific protection during the COVID-19 pandemic.
\end{abstract}

KEY WORDS: Hand hygiene. Specific protection. COVID-19.

\section{Apego a higiene de manos en 5 momentos y protección específica en un hospital de tercer nivel ante la pandemia de COVID-19}

\section{Resumen}

Introducción: Ante la pandemia de COVID-19, el apego a las medidas de higiene es un objetivo para disminuir la morbimortalidad. Objetivo: Evaluar el apego a la higiene de manos y medidas de protección durante la pandemia de COVID-19 en un hospital de tercer nivel. Métodos: Estudio transversal acerca del lavado de manos del personal de salud en los cinco tiempos recomendados por la Organización Mundial de la Salud, así como sobre el uso del equipo de protección personal específico. Resultados: Fueron observadas 117 oportunidades de higiene de manos en personal de salud: 40 (34 \%) respecto al lavado de manos y 76 (65\%) respecto a su omisión; sobre el apego al uso de careta en cinco (4\%) y sobre la falta de apego en 112 (96\%). Se identificó apego al uso de mascarilla en 65 profesionales de enfermería (87\%), uso adecuado de mascarilla en 56 de ellos (60 \%) y uso de careta en uno (1\%). Conclusión: El personal mostró baja proporción de apego a la higiene de manos y al uso de equipo para la protección específica durante la pandemia de COVID-19.

PALABRAS CLAVE: Higiene de manos. Protección específica. COVID-19.

Correspondence:

*Rodrigo A. Del Valle-Díaz de León

E-mail: r.alexxis91@gmail.com
Gac Med Mex. 2021;157:313-317

Contents available at PubMed

www.gacetamedicademexico.com

0016-3813/@ 2021 Academia Nacional de Medicina de México, A.C.. Published by Permanyer. This is an open access article under the CC BY-NC-ND license (http://creativecommons.org/licenses/by-nc-nd/4.0/). 


\section{Introduction}

It is important for health workers to be aware of personal protection measures, their proper use and indications, the importance of which was demonstrated during the COVID-19 pandemic by the high rate of contagions in health personnel, even with the use of protective measures. Behavior regarding adherence to hygiene measures in health workers has been reported not to significantly change despite public health information and prevention campaigns. ${ }^{1}$

The World Health Organization recommends various strategies for hand washing. Hand hygiene should be carried out at five moments: before touching a patient, before an aseptic procedure, after body fluid exposure/risk, after touching a patient, and after touching patient surroundings. ${ }^{2}$ Even when these strategies are accessible to different health systems, both in first-world and developing countries, they have not been promoted according to established goals. $^{3}$

Despite having sophisticated equipment for personal protection against infectious-contagious diseases, there are no studies of sufficient quality to show which is the best. ${ }^{4}$ Assessing the importance of compliance with hand hygiene and the proper use of protective equipment is a controversial issue, since health personnel have contracted COVID-19 despite these measures.

Demonstration of recommendations and strategies to improve handwashing hygiene and specific protection efficacy is crucial, both to motivate health workers behavior and to ensure preventive measures. However, research in this field represents a challenging activity.

To prevent these contagions among health personnel, the Center for Disease Control and Prevention of Atlanta, in the United States, recommends the use of $\mathrm{N}-95$ or higher protection level face masks in rooms with patients with suspected or confirmed COVID-19. ${ }^{5}$ The World Health Organization proposes the use of gloves, aprons, protective glasses, disposable gowns and $\mathrm{N}-95$ face masks during the management of these patients. ${ }^{6}$

Hand washing and specific precautions are important tools in the prevention of health-related infections. However, in spite of evidence in the reduction of infection transmission with these measures and of the fact that they are highly cost-effective, health personnel adherence is low. ${ }^{3,4.7}$ Up to $50 \%$ of infections have been shown to be preventable; hand washing is considered the best prevention method. On the other hand, various studies indicate an increased risk in health workers for contracting and spreading infectious diseases. ${ }^{8-10}$

Initially, the Mexican Institute of Social Security did not have a practice guideline on the use of protective equipment by health personnel for the care of patients with COVID-19, and thus the Ministry of Health proposed training in that sense - with an emphasis on infection prevention measures, hand hygiene, contact isolation, and N95 face mask adjustment tests - for the personnel who perform aerosol-generating procedures. ${ }^{11}$ Currently, the "Guidelines for the care of COVID patients" can be accessed. ${ }^{11}$ For the protection of health personnel, the World Health Organization recommends paying special attention to hand hygiene, use of face mask, sanitary gown, disposable gloves and eye protection googles. ${ }^{12}$ Indications for the use of these implements should be based on surroundings, recipients, risk of exposure (e.g., type of activity), and pathogen transmission dynamics (contact, respiratory droplets, aerosols, etc.). ${ }^{13}$

Protective equipment comprises the following elements:

- General protection glasses: with a minimum eye protection level recommended for laboratory use, which is why they must include side protection. It is recognized that they are not fully effective against contact by splashes. ${ }^{14}$

- Gloves: adapted to different clinical situations and can be made of latex, vinyl or nitrile.

- Surgical mask: used to protect the biological sample and the patient (although it does not protect the bearer), from respiratory droplets emission.

- Body protection: clinical gown, the use of which is indicated in all laboratories, according to the risk of exposure to flammable material or not; the most common is the traditional cotton or polyester gown. ${ }^{2}$

The purpose of this research is to know health personnel adherence to preventive measures such as hand washing and proper use of personal protective equipment within a hospital of the National Medical Center of the West, between November 2020 and January 2021.

\section{Method}

A cross-sectional, descriptive, prospective observational, study was carried out that included nursing 
personnel, doctors, residents and other categories of health workers who serve at the patient care area of a hybrid hospital of the National Medical Center of the West; using the shadow technique, whether hand hygiene and specific protection were carried out according to the established methodology was observed.

Sampling was determined by convenience, and the sample size was non-probabilistic because adherence of all personnel working at the hospital was evaluated.

Doctors from all specialties, staff and residents, nurses of all ranks and personnel of other types and all ranks, who worked at any hospital area, were included. Workers who noticed the presence of the evaluator were eliminated from the study.

The variables that were evaluated followed the guidelines of the measurement tool of the Institutional Model to Prevent and Reduce Nosocomial Infections, of the Mexican Institute of Social Security, which in turn is based on the tool recommended by the World Health Organization and that specifies the following: hand hygiene (at five moments), hand washing, hand rub (alcohol gel), face mask and protective glasses.

To evaluate adherence, two main investigators, who are part of the research team and work at the hospital where the study was carried out were assigned. These investigators were trained and received written material regarding indications and related concepts, in order for them to be able to apply the measurement tool, as well as to identify and differentiate the elements to be evaluated.

Each observer was positioned near the point of care; he was instructed to place the form on a solid support to facilitate the observation task. Each observer looked for any indication and turned it into an opportunity as he recorded it, using a special capture procedure. A fixed data collection period was assigned, according to the sample size, in search of opportunities to evaluate the action taken by health personnel; observers were told that at most they could record three health workers at the same time. The observation period was defined as the time span during which compliance was measured in a given scenario. Once observation on the studied subject was concluded, he/she was asked to authorize his/her participation as part of the sample by verbally granting informed consent. No names were collected in order to avoid measurement biases.
Table 1. Characteristics of 117 hygiene records in health personnel

\begin{tabular}{|l|c|c|}
\hline Characteristic & n & $\%$ \\
\hline Gender & & \\
\hline Males & 56 & 48.0 \\
Females & 61 & 52.0 \\
\hline Category & & \\
$\quad$ Nurse & 75 & 64.1 \\
Resident & 34 & 29.1 \\
Other & 6 & 5.1 \\
$\quad$ Staff physician & 2 & 1.7 \\
\hline Shift & & \\
$\quad$ Morning & & \\
Afternoon & 33 & 28.2 \\
$\quad$ Night & 16 & 13.7 \\
Full time workers & 23 & 19.7 \\
\hline Area of work & 45 & 38.5 \\
$\quad$ Emergency department & & \\
$\quad$ Hospitalization area & & 24.8 \\
$\quad$ COVID care unit & 29 & 64.1 \\
\hline
\end{tabular}

For the analysis of results, central tendency (mean, median, mode) and dispersion measures (standard deviation, lowest value and highest value), means and proportions estimation, as well as absolute and relative frequencies were used for qualitative variables. SPSS statistical program, version 24.0, was used. The study was approved by the ethics and research committee of the hospital.

\section{Results}

During observation, 117 "opportunities" for hand hygiene were identified in 102 different health personnel subjects; out of these opportunities, 61 (52 \%) corresponded to female personnel, 75 (64.1\%) to nursing personnel and 34 (29.1\%) to resident physicians; 45 (38.5 $\%$ ) corresponded to personnel who worked full time and $75(64.1 \%)$ to workers of hospitalization areas. The rest of characteristics of the 117 observations are detailed in table 1.

The opportunity for observation occurred before the health personnel touched the patient in $35 \%$ of occasions, after touching the patient in $40 \%$, after touching patient surroundings in $22 \%$ and before an aseptic procedure in $3 \%$. Within the observation of health personnel actions, hand washing was recorded on 40 occasions (34.18\%), and omission on 76 occasions $(64.9 \%)$. Regarding adherence to the use of protective equipment, the use of face shield was 
recorded in five observations (4\%) and no use of face shield in 112 (96\%). Regarding adherence to the use of face mask, 65 (87\%) observations were made in nursing personnel; in 56 (60\%), face mask use was adequate. Use of face shield was recorded on one occasion (1\%).

\section{Discussion}

Adherence to hand washing should not have a constant of change over time, since its benefits have been known for centuries. Frequent training should be carried out in order to maintain constant adherence to safety measures by health personnel, the patient, and the general population. However, adherence to hand washing is different with regard to place and time and is reinforced during and after epidemics or pandemics. In this study, a general frequency of hand washing of $34.18 \%$ was found in health personnel. A study carried out in 2007 at La Raza National Medical Center Specialty Hospital evaluated the prevalence and adherence to hand washing using the shadow technique, with a sample of 299 health workers. General prevalence of hand washing was $60.2 \%, 62 \%$ among nursing personnel, $57.6 \%$ among resident physicians, $75 \%$ among staff physicians, and $20 \%$ among inhalotherapists. ${ }^{15}$

In 2011, after the 2009 H1N1 influenza epidemic, a multimodal hand hygiene study was carried out at the Children's Hospital, National Medical Center Siglo XXI of the Mexican Institute of Social Security: the prevalence of hand washing was $51 \%$, and $38.9 \%$ did it at all five recommended moments $(p<0.05){ }^{16}$

Adherence to hand washing in this study was higher than in previous reports at the same institution, which is a finding similar to that reported by Labarca et al., ${ }^{7}$ who found higher adherence during the H1N1 influenza pandemic, in comparison with a previous period and a period after it. Although no cause was found for this effect, it can be attributed to the intense educational campaigns regarding prevention and the fear of contagion. It is important to consider the Hawthorne effect, a response induced by knowledge of the participants that they are being studied.

\section{Conclusion}

Higher adherence to protective measures was observed, higher than that reported at the same unit before the contingency. The nursing staff had the highest adherence frequency; however, following this line of research, it is important to point out that higher knowledge of protocols was found to be required, which may give rise to the implementation of orientation and health education measures, and would reinforce the protection of health personnel in the pandemic caused by SARS-CoV-2 virus and against other infections.

\section{Funding}

The present investigation did not receive any specific grant from agencies of the public, commercial or non-profit sectors.

\section{Conflict of interests}

The authors declare that they have no conflicts of interest.

\section{Ethical disclosures}

Protection of human and animal subjects. The authors declare that no experiments were performed on humans or animals for this research.

Confidentiality of data. The authors declare that no patient data appear in this article.

Right to privacy and informed consent. The authors declare that no patient data appear in this article.

\section{References}

1. Pires-Dos Santos R, Konkewicz LR, Nagel F, Lisboa T, Jacoby T, Ludwig-Gastal S, et al. The 2009 H1N1 influenza A pandemic and hand hygiene practices in a hospital in the South of Brazil. Infect Control Hosp Epidemiol. 2010;31:131301315

2. Organización Mundial de la Salud [Internet]. Switzerland: Prevención y control de infecciones en los centros de atención de larga estancia en el contexto de la COVID-19: orientaciones provisionales; 2020.

3. Bolon MK. Hand hygiene: an update. Infect Dis Clin North Am. 2016;30:5910607.

4. Allegranzi B, Pittet D. Role of hand hygiene in healthcare-associated infection prevention. J Hosp Infect. 2009;73:305ロ315.

5. Heinzerling A, Stuckey P, Scheuer T, Xu K, Perkins K, Resseger H, et al. Transmission of COVID-19 to health care personnel during exposures to a hospitalized patient - Solano County, California, February 2020. MMWR Morb Mortal Wkly Rep. 2020;69:472.

6. World Health Organization [Internet]. Switzerland: Rational use of personal protective equipment for coronavirus disease (COVID-19) and considerations during severe shortages; 2020.

7. Labarca J, Zambrano A, Niklitschek S, Ferrés M, Pérez C, Ajenjo MC, et al. H1N1 pandemic influenza impact on hand hygiene and specific precautions compliance among healthcare workers. J Hosp Infect. 2011;79(2):177ロ179.

8. Lydon S, Power M, McSharry J, Byrne M, Madden C, O'Connor P, et al. Interventions to improve hand hygiene compliance in the ICU: a systematic review. Crit Care Med. 2017;45:e1165ロe1172.

9. Jiang L, Ng IHL, Hou Y, Li D, Lin-Tan LW, An-Ho HJ, et al. Infectious disease transmission: survey of contacts between hospital-based healthcare workers and working adults from the general population. J Hosp Infect. 2018;98:404ロ411. 
10. Huttunen R, Syrjänen J. Healthcare workers as vectors of infectious diseases. Eur J Clin Microbiol Infect Dis. 2014;33(9):147701488.

11. Lineamiento para la atención de pacientes por COVID 19 [Internet] Mexico: Comisión Coordinadora de Institutos Nacionales de Salud y Hospitales de Alta Especialidad/Secretaria de Salud; 2020.

12. Uso racional del equipo de protección personal frente a la COVID-19 y aspectos que considerar en situaciones de escasez graves: orientaciones provisionales, April 6, 2020 [Internet]. Switzerland: World Health Organization; 2020.

13. Organización Mundial de la Salud [Internet]. Switzerland: Prevención y control de infecciones durante la atención sanitaria de casos en los que se sospecha una infección por el nuevo coronavirus (nCoV): orientaciones provisionales. [Available: 2020 Jan 25].
14. Allegranzi B, Gayet-Ageron A, Damani N, Bengaly L, McLaws ML, Urroz O, et al. Global implementation of WHO's multimodal strategy for improvement of hand hygiene: a quasi-experimental study. Lancet Infect Dis. 2013;13:843ロ851.

15. Anaya-Flores VE, Ortiz-López S, García-Hernández A, Jiménez-Bravo ML, Ángeles-Garay $U$, et al. Prevalencia de lavado de manos y factores asociados con el incumplimiento. Estudio de sombra. Rev Enferm Inst Mex Seguro Soc. 2007;15:141-146.

16. Zamudio-Lugo I, Meza-Chávez A, Martínez-Sánchez Y, Miranda-Novales MG, Espinosa-Vital JG, Rodríguez-Sing R. Estudio multimodal de higiene de manos en un hospital pediátrico de tercer nivel. Bol Med Hosp Infant Mex. 2012;69:384-390. 